\title{
Release of DNA from cryogel PVA-DNA membranes
}

\author{
A. J. M. Valente ${ }^{*}$, S. M. A. Cruz ${ }^{1}$, M.C. Morán ${ }^{1}$, D. B. Murtinho ${ }^{1}$, E. C. Muniz ${ }^{2}$, M. G. Miguel ${ }^{1}$ \\ ${ }^{1}$ Department of Chemistry, University of Coimbra, 3004-535 Coimbra, Portugal \\ ${ }^{2}$ Grupo de Materiais Poliméricos e Compósitos, GMPC, Departamento de Química, Universidade Estadual de Maringá, \\ 87020-900 - Maringá, PR, Brazil
}

Received 7 January 2010; accepted in revised form 17 March 2010

\begin{abstract}
Poly(vinyl alcohol) (PVA) hydrogels have been used for numerous biomedical and pharmaceutical applications, as a consequence of their non-toxic, non-carcinogenic and bioadhesive properties. In this communication the effect of different factors, such as type of electrolyte, ionic strength, temperature (ranging from 20 to $40^{\circ} \mathrm{C}$ ) and cationic surfactants on the distribution coefficients $(\alpha)$ and release rate constants $\left(k_{R}\right)$ of deoxyribonucleic acid (DNA) from PVA-DNA blend gel matrices (of a sheet shape), will be presented and discussed. The release kinetic constant and the distribution coefficient of DNA are quite sensitive to the surrounding matrix media (e.g., $k_{R}$ ranges from $1.5 \cdot 10^{-8}$ to $4.7 \cdot 10^{-7} \mathrm{~s}^{-1}$ ). The analysis of the temperature dependence on $k_{R}$ shows that the activation energy for the DNA desorption to an aqueous solution is equal to $21.2 \mathrm{~kJ} / \mathrm{mol}$. These results constitute a step forward towards the design of controlled DNA release PVA-based devices.
\end{abstract}

Keywords: polymer gels, polymers membranes, poly(vinyl alcohol), deoxyribonucleic acid, release kinetics

\section{Introduction}

Hydrogels are polymeric materials with a threedimensional network structure that can imbibe water, buffered or physiological solutions. Hydrogels show high water content, soft and rubbery consistency and low interfacial tension with water or biological fluids [1]. The ability of molecules of different size to diffuse into (drug loading), and out of (drug release) hydrogels, allows the use of hydrogels as delivery systems $[2,3]$.

In recent years, there has been considerable work performed in the development of cross-linked polymeric networks which are sensitive to their surrounding physiological environment and therefore will be desirable systems for site-specific drugdelivery [4-9].

Poly(vinyl alcohol) (PVA) is commonly used as a component to form hydrogels. PVA and its copolymers have been widely employed in controlled drug release systems [10]. PVA is hydrophilic and easily swells upon hydration [11]. Furthermore, PVA is non-toxic, non-carcinogenic, shows bioadhesive characteristics and is easily processed [12]. These properties make it ideal for biomedical uses, especially in drug delivery systems. PVA hydrogels can be cross-linked through the use of bifunctional agents, by using electron beam or $\gamma$-radiation, or by a 'freezing-thawing' process [13]. The later process addresses toxicity issues; furthermore, these physically cross-linked materials also exhibit higher mechanical strength and elasticity than PVA gels prepared by other methods [13]. Characterization and properties of the so-called PVA-based cryogels have been summarized by V. I. Lozinsky [14, 15]. Recently we have reported the encapsulation of deoxyribonucleic acid (DNA) into PVA hydrogels, obtained by a technique of repeated freezing and thawing [16]. The obtained cryogels were chemically and physically characterized, and show a good mechanical resistance and a white and opaque 
appearance due to a heterogeneous porous structure. Furthermore, the encapsulated DNA molecules can be compacted or extended in the PVA matrix by tailoring the crystallinity degree of the PVA network.

In this paper the effect of different factors, such as electrolytes, ionic strength, cationic surfactants and temperature (ranging from 25 to $50^{\circ} \mathrm{C}$ ) on the distribution coefficients $(\alpha)$ and release rate constants $\left(k_{R}\right)$ of DNA from PVA-DNA blend gel matrices (of a sheet shape), will be presented and discussed. The kinetics of release will be evaluated by a reversible first-order kinetic law equation, developed by Reis et al. [17], based on the assumption that the release of a solute from a hydrogel is treated as a partition phenomenon.

\section{Experimental}

\subsection{Reagents and materials}

Poly(vinyl alcohol) (PVA) (molecular weight $\left(M_{w}\right)$ 72000 , degree of polymerization $\sim 1600$, degree of hydrolysis $97.5-99.5 \mathrm{~mol} \%$ ) was supplied from Fluka (Steinheim, Germany). The sodium salt of deoxyribonucleic acid (DNA) from salmon testes of an average degree of polymerization of about 2000 base pairs was purchased from Sigma (Steinheim, Germany) and used as received. Sodium bromide, $\mathrm{NaBr}$, (Merck, Darmstadt, Germany), sodium iodide, NaI (Merck, Darmstadt, Germany), sodium nitrate, $\mathrm{NaNO}_{3}$ (Riedel-de Haën, Seelze, Germany), and sodium chloride, $\mathrm{NaCl}$ (Riedel-de Haën, Seelze, Germany) all of pro analysis grade, were used as received.

The fluorescence dye $N, N, N^{\prime}, N^{\prime}$-tetramethylacridine-3,6-diamine (acridine orange (AO)) was purchased from Molecular Probes (Invitrogen, Eugene, OR, USA).

These reagents were used without further purification. All solutions were prepared using Millipore-Q water.

\subsection{Surfactant synthesis}

The 1,12-dibromododecane (Aldrich, Steinheim, Germany), (10 mmol) was dissolved in $20-25 \mathrm{ml}$ dry ethanol and $200 \mathrm{mmol}$ of amine (triethylamine or an ethanolic solution of trimethylamine, 31$35 \%$ ) were added. The reaction mixture was refluxed until the alkylbromide was consumed, usually $48 \mathrm{~h}$, as monitored by TLC. The solvent and the excess amine were evaporated under reduced pressure and the residue was crystallized several times from the appropriate solvent or solvent mixtures.

Dodecane-1,12-bis(trimethylammonium bromide), $\mathrm{C}_{12} \mathrm{Me}_{6}$ : Crystallized in ethanol, $93 \%$ yield.

Dodecane-1,12-bis(triethylammonium bromide), $\mathrm{C}_{12} \mathrm{Et}_{6}$ : Crystallized in $\mathrm{CH}_{2} \mathrm{Cl}_{2} /$ ethyl acetate, $85 \%$ yield.

\subsection{Preparation of PVA-DNA gel matrices}

A PVA solution of $14 \mathrm{wt} \%$ concentration was prepared by dissolving the appropriate amount of PVA into distilled water at $80^{\circ} \mathrm{C}$ under continuous stirring for three hours. An accurate amount of DNA (ca. 1\% w/w), using a Scaltec SBC22 (Göttingen, Germany) balance with a resolution of $\pm 0.01 \mathrm{mg}$, was added to $1 \mathrm{~g}$ of PVA solution, at room temperature, and mixed, under continuously stirring, during 4 hours. After that, the solution was casted into cylinder flasks and submitted to freezing for 12 hours at $-20^{\circ} \mathrm{C}$ and, after that, thawed for 12 hours at $+25^{\circ} \mathrm{C}$. The cycles of freezing and thawing were repeated three times. After that, the blend gel membrane, of $2.20( \pm 0.04) \mathrm{mm}$ thickness - measured by a digimatic micrometer Mitutoyo (Kawasaki, Japan) with a resolution of $0.001 \mathrm{~mm}-$ shows a good mechanical resistance and a white and opaque appearance.

\subsection{Desorption kinetics of DNA}

DNA desorption kinetics were performed by immersing a PVA-DNA gel membrane sample (as it was synthesised) in $100 \mathrm{ml}$ of liquid (water, salt or surfactant solution). Experiments have been carried out at $20^{\circ} \mathrm{C}$. The effect of temperature on the release kinetics of DNA has been studied in the 20 to $40^{\circ} \mathrm{C}$ temperature range. In all experiments, temperature was kept constant by using a thermostatic bath Multistirrer 6 from Velp Scientifica (Milan, Italy). During DNA release experiments gel-containing solutions were stirred at ca. $220 \mathrm{rpm}$. At defined intervals, aliquots of the supernatant were collected. The amount of substance of DNA released from polymeric matrices, $n_{R, t}$, to the supernatant solution was determined by UV-vis spectrophotometry, by measuring the absorbance at $260 \mathrm{~nm}$ with a Jasco V-530 (Essex, UK) spectrophotome- 
ter, and using the extinction coefficient of $6600 \mathrm{M}^{-1} \cdot \mathrm{cm}^{-1}[18,19]$.

\subsection{Fluorescence microscopy}

Freshly prepared membranes or supernatant solutions derived from the DNA release studies were stained with $N, N, N^{\prime}, N^{\prime}$-tetramethylacridine-3,6diamine (acridine orange, AO), a nucleic acid selective fluorescent cationic dye, used to confirm the presence of DNA in the membranes. In addition, using AO, information about the secondary structure of the nucleic acid in the membranes has been obtained [20].

Stained samples were immediately examined with an Olympus BX51M (Hamburg, Germany) microscope equipped with a UV-mercury lamp (100W Ushio Olympus) and a filter set type MNIBA3 (470$495 \mathrm{~nm}$ excitation and $505 \mathrm{~nm}$ dichromatic mirror). The PVA-DNA membranes were observed using an Olympus $4 \times / 0.10$ objective lens ( $\infty /-/ F N 22)$; supernatant solutions were observed using an Olympus 100×/1.30 oil-immersed objective lens (Hamburg, Germany).

Images were digitized on a computer through a video camera (Olympus digital camera DP70) and were analyzed with an image processor (Olympus DP Controller 2.1.1.176, Olympus DP Manager 2.1.1.158 - Olympus, Hamburg, Germany). All observations were carried out at $20^{\circ} \mathrm{C}$.

Figure 1 shows modification on the surface morphology of PVA gel matrices in the absence and presence of DNA. It is possible to observe that DNA is distributed throughout all matrix, confirming the effectiveness of the mixing method.

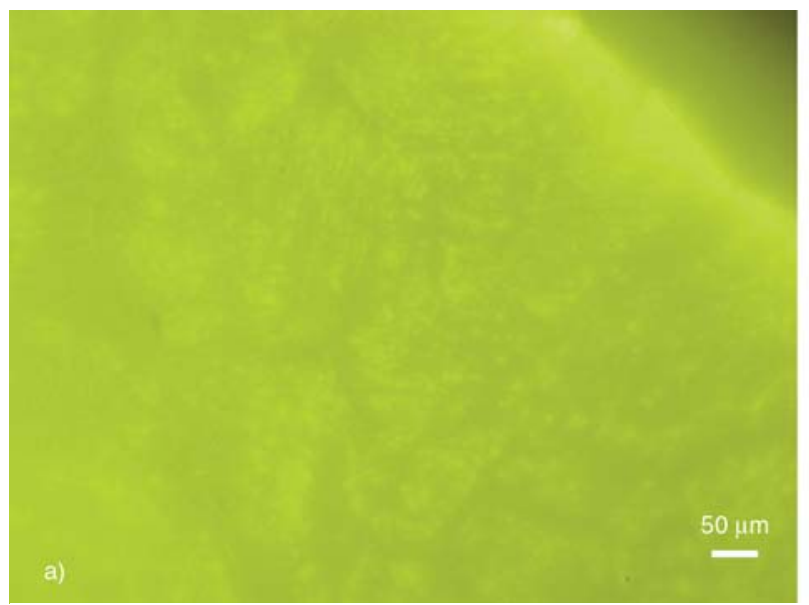

Figure 1. Fluorescence microscopy images for PVA blend matrix in the absence (a) and presence (b) of DNA

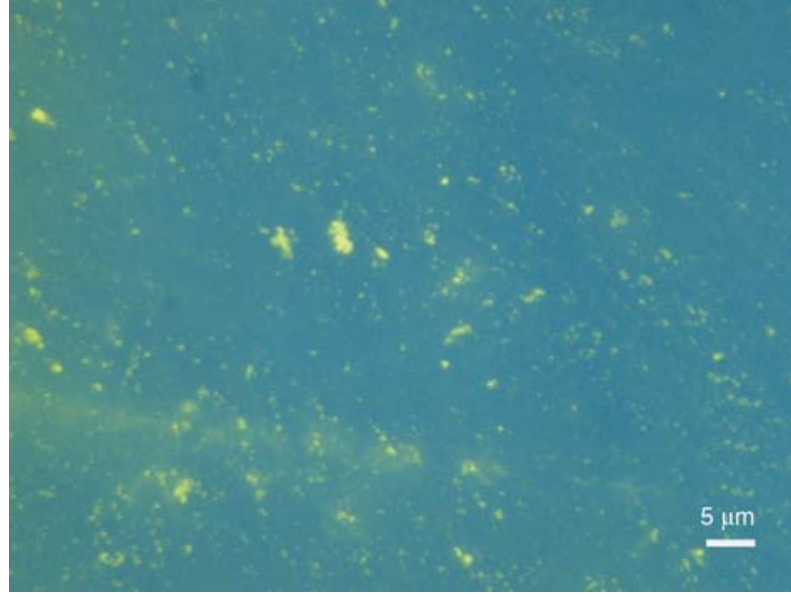

Figure 2. Fluorescence microscopy photograph of an aqueous supernatant solution of water in contact with PVA-DNA gel membrane

The secondary structure of DNA desorbed from PVA-DNA gel was also checked by fluorescence microscopy. Based on the observation of green or red fluorescence, acridine orange has been used to differentiate native, double-stranded DNA from denatured, single-stranded DNA [20]. Although the size of the observed objects suggests that the delivery of DNA is in the form of aggregates, no evidences of denaturation of DNA have been found (Figure 2).

\section{Mathematical model}

The quantification of the release kinetics of DNA has been done taking into account the initial and border conditions of a non-steady state diffusion transport occurring in a stirred solution of limited volume [21]. Recently, Reis et al. [17] developed a set of equations to model the release of dyes from

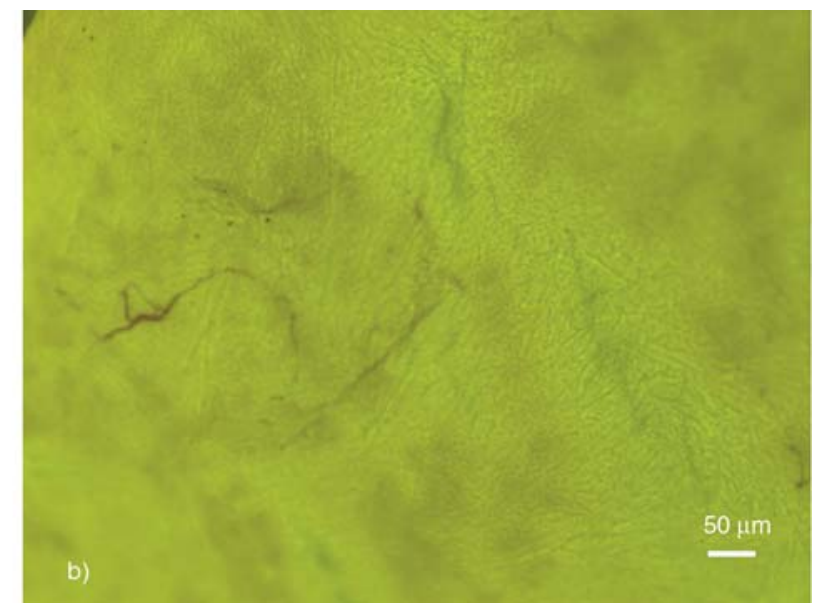


poly( $N$-isopropylacrylamide)-polyacrylamide taking into account the previous mentioned conditions, and treating the release of a solute from the gel as a partition phenomena, where the partitioning of such solute occurs between a solvent (or solution) phase and the hydrogel.

This behaviour can be quantified through the distribution coefficient, $\alpha$, which characterizes the physical chemical affinity of the solute for both phases (Equation (1)):

$\alpha=\frac{F_{R, \max }}{1-F_{R, \max }}$

where $F_{R \text {,max }}$ is the maximum fraction of the released solute, and $F_{R}$ is given by Equation (2):

$F_{R}=\frac{C_{R, t}}{C_{0}}$

where $C_{R, t}$ is the concentration of the solute released, at time $t$, and $C_{0}$ is the initial concentration of the loaded solute inside gel matrix.

When $t>0$, the diffusion of the solute between the hydrogel and the solution phase occurs, and the process of release and absorption of solute occurs simultaneously.

Assuming a first order kinetic process, changes of solute concentration in solution at a given time $t$, can be expressed as Equation (3):

$\frac{\mathrm{d} C_{R, t}}{\mathrm{~d} t}=k_{R}\left(C_{0}-C_{R, t}\right)-k_{A}\left(C_{R, 0}-C_{A, t}\right)$

where $C_{R, 0}$ and $C_{R, t}$ are the concentration of the release solute at $t=0$ and at time $t, C_{0}$ is the initial concentration of DNA in the gel and $C_{A, t}$ is the concentration of absorbed solute at specific time $t . k_{R}$ and $k_{A}$ are the rate constants for the release and absorption processes, respectively.

From the kinetic law equation, Equation (3), and taking into account considerations reported elsewhere [17], the release kinetics of DNA can be treated by using Equation (4):

$F_{R}=F_{R, \max }\left(1-e^{-\left(k_{R} / F_{R, \max }\right) t}\right)$

where $F_{R, \max }=C_{R, \max } / C_{0}$, and $C_{R, \max }$ is the maximum concentration of solute in solution released from the gel. By fitting Equation (4) to experimental data (e.g., Figure 3 ) it is possible to calculate the following parameters: $F_{R \text {,max }}$ and $k_{R}$, and so to char-
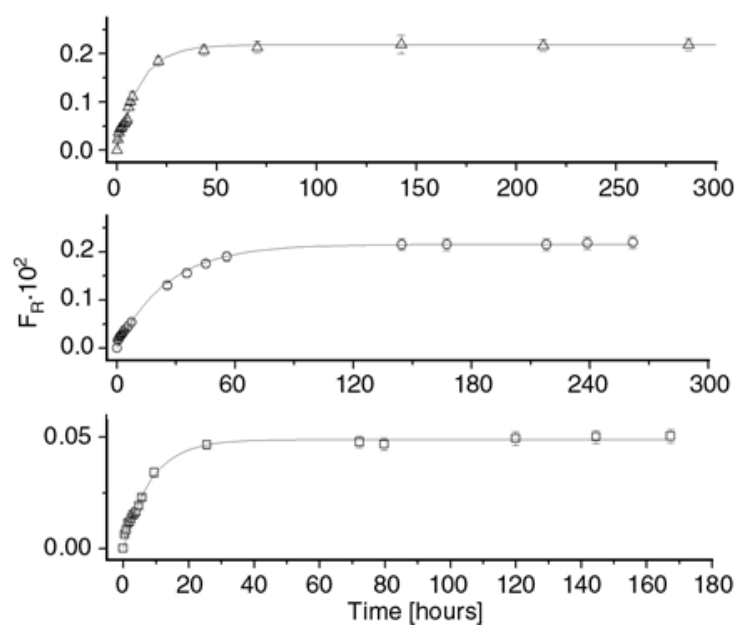

Figure 3. Desorption kinetics of DNA from PVA-DNA membranes to cationic surfactant solution: $(\square)$ $\mathrm{C}_{12} \mathrm{TAB},(\mathrm{o}) \mathrm{C}_{12} \mathrm{Me}_{6},(\Delta) \mathrm{C}_{12} \mathrm{Et}_{6}$. Solid lines represent the fraction of release DNA predicted by Equation (4).

acterise the release not only in terms of kinetics, but also in terms of the partition coefficient.

It is worthwhile to note that the release of DNA, in all systems mentioned in this communication, follows a first-order kinetic law. The experimental data were analyzed using a nonlinear least-squares fitting procedure (Origin 8.0), using a 95\% confidence level. The uncertainty in the fit of Equation (4) to the data is in general smaller than $5 \%$.

\section{Results and discussion}

\subsection{Effect of symmetrical and unsymmetrical electrolytes}

Table 1 shows the effect of sodium salts on the distribution coefficient $(\alpha)$ and released rate constants $\left(k_{R}\right)$ of DNA release from PVA-DNA gel membranes in different electrolyte media.

It is possible to observe that comparing the release of DNA to sodium salts, at a given concentration, there is a decrease of both $\alpha$ and $k_{R}$ in the order: $\mathrm{NaI}>\mathrm{NaNO}_{3}>\mathrm{NaCl}>\mathrm{NaBr}$. The order of anions does not differ much from that involved in their water structure modifying effects or of the Hofmeister series $[22,23]$; that is, with the capacity of different aqueous solutions to solubilise DNA. Lozinsky et al. [24] have also reported that the reinforcing ability of the electrolyte with respect to the PVA cryogel strength has been shown to be in agreement with the position of these ions in the 
Table 1. Values of different kinetic and equilibrium parameters for the release of DNA, from PVA cryogels, to different electrolyte solutions, at $25^{\circ} \mathrm{C}$

\begin{tabular}{|c|c|c|}
\hline & $\alpha / \mathbf{1 0}^{-3}$ & $\mathbf{k}_{\mathrm{R}} \cdot 10^{-7}\left[\mathrm{~s}^{-1}\right]$ \\
\hline \multicolumn{3}{|l|}{$[\mathrm{NaI}][\mathrm{mM}]$} \\
\hline 10 & $4.7( \pm 0.1)$ & $4.8( \pm 0.3)$ \\
\hline 25 & $4.6( \pm 0.1)$ & $1.33( \pm 0.09)$ \\
\hline 50 & $3.33( \pm 0.06)$ & $1.07( \pm 0.04)$ \\
\hline \multicolumn{3}{|c|}{$\left[\mathrm{NaNO}_{3}\right][\mathrm{mM}]$} \\
\hline 10 & $3.43( \pm 0.08)$ & $1.92( \pm 0.09)$ \\
\hline 25 & $3.31( \pm 0.05)$ & $1.19( \pm 0.03)$ \\
\hline 50 & $2.51( \pm 0.07)$ & $4.66( \pm 0.02)$ \\
\hline \multicolumn{3}{|l|}{$[\mathrm{NaCl}][\mathrm{mM}]$} \\
\hline 10 & $2.81( \pm 0.06)$ & $1.27( \pm 0.05)$ \\
\hline 25 & $2.54( \pm 0.07)$ & $0.66( \pm 0.03)$ \\
\hline 50 & $2.08( \pm 0.05)$ & $0.40( \pm 0.02)$ \\
\hline \multicolumn{3}{|c|}{$[\mathrm{NaBr}][\mathrm{mM}]$} \\
\hline 10 & $2.37( \pm 0.07)$ & $0.83( \pm 0.05)$ \\
\hline 25 & $2.24( \pm 0.01)$ & $0.462( \pm 0.008)$ \\
\hline 50 & $1.05( \pm 0.01)$ & $0.128( \pm 0.004)$ \\
\hline
\end{tabular}

Values inside brackets correspond to standard deviations.

lyotropic series. Among these salts, iodide solution has the strongest effect as water structure breaking, being the highest effective on the solubilisation of DNA [25]. Using similar arguments, $\mathrm{NaBr}$ is the less effective on the solubilisation of DNA in the aqueous phase [20]. We can hypothesise that such variation in the empirical sequence, when compared with the Hofmeister series, can be justified by the specific effect of bromide ions on the crystallinity of PVA and/or on the DNA structure. That is, the presence of bromide ions affects the PVA structure by decreasing its crystallinity due to the ability of $\mathrm{NaBr}$ as a hydrogen bond breaker [26]; consequently, it can be suggested that in more amorphous gels, due to the higher mobility of the PVA chains between the crystalline parts, DNA molecules evidenced stronger self interactions, generating aggregate structures and, thus, increasing the retention $(\alpha)$ of DNA inside the gel membrane. On the other hand, the effect of $\mathrm{NaBr}$, on the DNA structure, in the gel membrane, is similar to that found by the addition of an azobenzene trimethylammonium bromide surfactant in DNA aqueous solution upon exposure to visible radiation [27]. Using the same arguments, the decrease in the rate constant of the DNA release with an increase of the retention degree can be attributed to a stabilization of DNA in the gel state. The last argument is also justified by the analysis of the effect of ionic strength on the partition coefficient and release rate constant of DNA from PVA membranes. The analysis of data (Table 1) suggests that an increase of the ionic strength leads to a higher retention of DNA inside gel, leading to an increase of DNA concentration gradient and, consequently, to a lower $k_{R}$. This can be justified by a salting-in phenomena [28], which contribute for a stabilization of the DNA inside the gel phase. Such stabilization occurs via aggregation of DNA. Consequently, the ability of DNA to diffuse out of gel decreases by steric hindrance [29] and/or by an increase of the resistance coefficient, which is a measure of the friction acting on a solute as it moves through a solvent (the friction acting on an aggregate is higher than that acting on a single molecule) [30].

\subsection{Effect of temperature}

The effect of temperature on the release of DNA from PVA-DNA gels to unbuffered water was evaluated at $20,30,37$ and $40^{\circ} \mathrm{C}$. Figure $4 \mathrm{a}$, shows the temperature dependency of drug release. It can be seen that the release is temperature-dependent, and $\alpha$ and $k_{R}$ increase by increasing temperature. It is interesting to note that the rate and distribution coefficients obtained for the release of DNA at $20^{\circ} \mathrm{C}$ in water is similar to those found for a solution of sodium nitrate $10 \mathrm{mM}$. With such results we can hypothesise that the delivery DNA mechanism is the same even in the absence of salt.

The temperature dependence of the rate constant, $k_{R}$, can be described by the Arrhenius relationship Equation (5):

$k_{R}=k_{0} e^{-\left(E_{a} / R T\right)}$

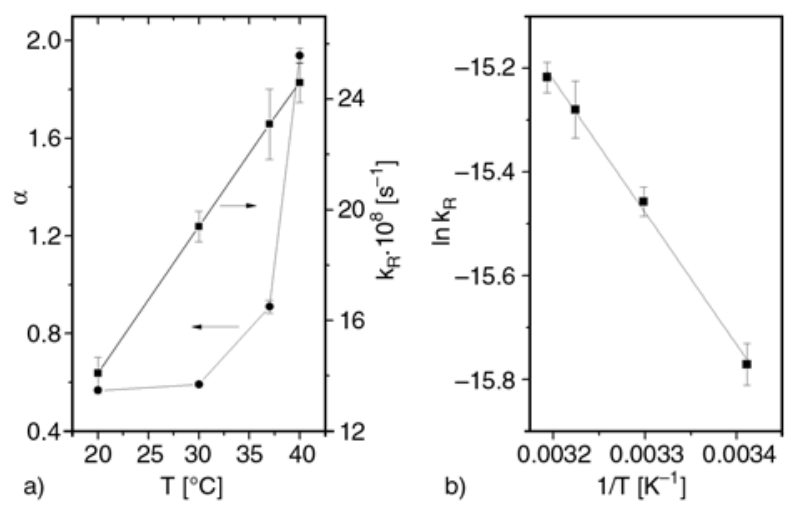

Figure 4. (a) Effect of temperature on the rate constants and distribution coefficients of DNA released from PVA-DNA membranes, (b) Arrhenius treatment of the temperature dependence of the rate constant, $k_{R}$ 
where $k_{0}$ is the preexponential factor, $E_{a}$ is the activation energy, $R$ is the universal gas constant, and $T$ is the absolute temperature. One can determine the value of $E_{a}$ from the slope of the linear relationship between $\ln k$ and the reciprocal of absolute temperature as demonstrated in Figure 4b. It was found that $E_{a}=21.2( \pm 0.8) \mathrm{kJ} / \mathrm{mol}$. This value is in agreement with the previously reported activation energy for the mobility of DNA in cross-linked polyacrylamide slabs gels (ca. $16 \mathrm{~kJ} / \mathrm{mol}$ for $700 \mathrm{bp}$ DNA) [31].

\subsection{Effect of cationic surfactants}

Cationic surfactants interact strongly with DNA. Those interactions depend on the surfactant hydrophobic chain length, charge and headgroup $[32,33]$. Figure 5 shows the effect of those factors on the release kinetics and distribution coefficient of DNA, from DNA-containing PVA gel matrices, to dodecyl-based cationic and di-cationic surfactants. All experiments have been carried out using surfactant solutions at pre-micelle concentrations. The distribution coefficient of DNA in the presence of $\mathrm{C}_{12} \mathrm{TAB}$ shows that almost all DNA is retained inside gel matrix (the cumulative DNA release is just 5\%) [34]. The high retention of DNA inside cryogel, when in the presence of aqueous solutions of dodecyltrimethylammonium bromide, can be justified by the formation of a coating-like structure [35] on the PVA-DNA gel, formed as a consequence of strong interaction between the desorbed DNA and the sorbed surfactant. Upon surfactant charge increase the cumulative release of DNA also increase to around $20 \%$. These values suggest that

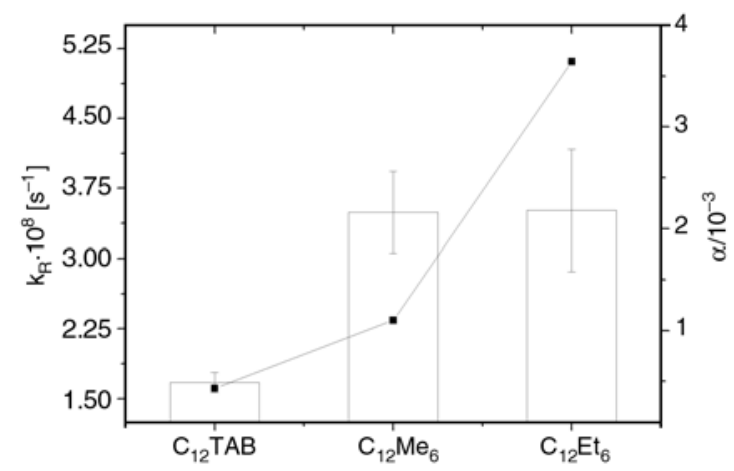

Figure 5. Distribution coefficients, $\alpha$ (columns), and rate constants, $k_{R}$ (data points), for the release of DNA, from PVA-DNA membranes, to aqueous solutions of different surfactants at $20^{\circ} \mathrm{C}$ interaction between $\mathrm{C}_{12} \mathrm{TAB}$ and DNA is much stronger than with di-cationic surfactants, as has been reported elsewhere [16]. On the other hand, there is no effect of the bulkiness head group, of the bolaamphiphile surfactants, on the distribution coefficients of DNA [33].

However, it should be noted that the rate constants increase in the same order $k_{R}\left(\mathrm{C}_{12} \mathrm{TAB}\right)<$ $k_{R}\left(\mathrm{C}_{12} \mathrm{Me}_{6}\right)<k_{R}\left(\mathrm{C}_{12} \mathrm{Et}_{6}\right)$, suggesting that the interactions between surfactants and DNA will affect the kinetics mechanism of release.

The main conclusion is that the release of DNA to a surfactant solution is quite sensitive to the balance between hydrophobic/hydrophilic and electrostatic interactions. Further studies have been carried out in order to have a deeper insight on such release mechanisms.

\section{Conclusions}

The kinetics and equilibrium properties of the release of DNA from PVA-DNA cryogel membranes to different solutions and temperatures have been studied. The first order kinetic law equation was found to be an excellent model to describe the experimental release data. The kinetics of release and the maximum amount of DNA desorbed are quite sensitive to the media where the PVA-DNA gel matrix is immersed. The rate of DNA release from PVA-DNA gels increased with increasing temperature with activation energy $\left(E_{a}\right)$ of $21.2 \mathrm{~kJ} / \mathrm{mol}$.

Kinetic and equilibrium parameters show that it will be possible to control the release of DNA, which, coupled with the very good mechanical stability of these gel blends, are promising results for the further development of more appropriated PVA matrices, loaded with DNA, for biomedical and pharmaceutical applications. Furthermore, our results show that a simple method can provide useful experimental information on the importance of ion-ion correlation effects in electrolyte-containing DNA solutions.

\section{Acknowledgements}

We are grateful to Prof. Bjorn Lindman for his valuable comments on this paper. We thank FCT (Project PTDC/ QUI/67962/2006) for financial support. 


\section{References}

[1] Peppas N. A.: Hydrogels in medicine and pharmacy. vol I-III. CRC Press, Boca Raton (1986).

[2] Amsden B.: Solute diffusion within hydrogels. Mechanisms and models. Macromolecules, 31, 8382-8395 (1998).

DOI: $\underline{10.1021 / \mathrm{ma9} 80765 \mathrm{f}}$

[3] Satish C. S., Satish K. P., Shivakumar H. G.: Hydrogels as controlled drug delivery systems: Synthesis, crosslinking, water and drug transport mechanism. Indian Journal of Pharmaceutical Sciences, 68, 133140 (2006).

DOI: $10.4103 / 0250-474 X .25706$

[4] Bayer C. L., Peppas N. A.: Advances in recognitive, conductive and responsive delivery systems. Journal of Controlled Release, 132, 216-221 (2008). DOI: 10.1016/j.jconrel.2008.06.021

[5] Leach J. B., Schmidt C. E.: Characterization of protein release from photocrosslinkable hyaluronic acid-polyethylene glycol hydrogel tissue engineering scaffolds. Biomaterials, 26, 125-135 (2005).

DOI: $10.1016 /$ j.biomaterials.2004.02.018

[6] del Valle E. M. M., Galan M. A., Carbonell R. G.: Drug delivery technologies: The way forward in the new decade. Industrial and Engineering Chemistry Research, 48, 2475-2486 (2009).

DOI: $10.1021 / \mathrm{ie} 800886 \mathrm{~m}$

[7] He C. L., Kim S. W., Lee D. S.: In situ gelling stimulisensitive block copolymer hydrogels for drug delivery. Journal of Controlled Release, 127, 189-207 (2008). DOI: $10.1016 /$ j.jconrel.2008.01.005

[8] Oh J. K., Drumright R., Siegwart D. J., Matyjaszewski K.: The development of microgels/nanogels for drug delivery applications. Progress in Polymer Science, 33, 448-477 (2008).

DOI: 10.1016/j.progpolymsci.2008.01.002

[9] Klouda L., Mikos A. G.: Thermoresponsive hydrogels in biomedical applications. European Journal of Pharmaceutics and Biopharmaceutics, 68, 34-45 (2008). DOI: $10.1016 /$ j.ejpb.2007.02.025

[10] Juntanon K., Niamlang S., Rujiravanit R., Sirivat A.: Electrically controlled release of sulfosalicylic acid from crosslinked poly(vinyl alcohol) hydrogel. International Journal of Pharmaceutics, 356, 1-11 (2008). DOI: 10.1016/j.ijpharm.2007.12.023

[11] Patachia S., Valente A. J. M., Baciu C.: Effect of nonassociated electrolyte solutions on the behaviour of poly(vinyl alcohol)-based hydrogels. European Polymer Journal, 43, 460-467 (2007).

DOI: 10.1016/j.eurpolymj.2006.11.009

[12] DeMerlis C. C., Schoneker D. R.: Review of the oral toxicity of polyvinyl alcohol (PVA). Food and Chemical Toxicology, 41, 319-326 (2003).

DOI: $10.1016 / \mathrm{S} 0278-6915(02) 00258-2$
[13] Hassan C. M., Peppas N. A.: Structure and applications of poly(vinyl alcohol) hydrogels produced by conventional crosslinking or by freezing/thawing methods. Advances in Polymer Science, 153, 37-65 (2000).

DOI: $10.1007 / 3-540-46414-X 2$

[14] Lozinsky V. I.: Cryogels on the basis of natural and synthetic polymers: Preparation, properties and application. Russian Chemical Reviews, 71, 489-511 (2002).

DOI: 10.1070/RC2002v071n06ABEH000720

[15] Lozinsky V. I.: Cryotropic gelation of poly(vinyl alcohol) solutions. Russian Chemical Reviews, 67, 573586 (1998). DOI: $10.1070 / \mathrm{RC} 1998 \mathrm{v} 067 \mathrm{n} 07 \mathrm{ABEH} 000399$

[16] Papancea A., Valente A. J. M., Miguel M. G., Lindman B.: PVA-DNA cryogel membranes: Characterization, swelling, and transport studies. Langmuir, 24, 273-279 (2008).

DOI: $\underline{10.1021 / 1 a 702639 d}$

[17] Reis A. V., Guilherme M. R., Rubira A. F., Muniz E. C.: Mathematical model for the prediction of the overall profile of in vitro solute release from polymer networks. Journal of Colloid and Interface Science, 310, 128-135 (2007). DOI: $10.1016 /$ j.jcis.2006.12.058

[18] Beach L., Schweitzer C., Scaiano J. C.: Direct determination of single-to-double stranded DNA ratio in solution using steady-state fluorescence measurements. Organic and Biomolecular Chemistry, 1, 450 451 (2003). DOI: $10.1039 / \mathrm{b} 209284 \mathrm{k}$

[19] Rosa M., Dias R., Miguel M. G., Lindman B.: DNAcationic surfactant interactions are different for double- and single-stranded DNA. Biomacromolecules, 6 , 2164-2171 (2005).

DOI: $10.1021 / \mathrm{bm} 050137 \mathrm{n}$

[20] Morán M. C., Miguel M. G., Lindman B.: DNA gel particles. Soft Matter, (in press) (2010). DOI: $10.1039 / \mathrm{b} 923873 \mathrm{e}$

[21] Crank J.: The mathematics of diffusion. Oxford University press, Oxford (1975).

[22] Lindman B., Forsen S., Forslind E.: Nuclear quadrupole relaxation of bromine-79 in aqueous solutions of quaternary ammonium bromides. The Journal of Physical Chemistry, 72, 2805-2813 (1968).

DOI: $\underline{10.1021 / \mathrm{j} 100854 \mathrm{a} 020}$

[23] Marcus Y.: Effect of ions on the structure of water: Structure making and breaking. Chemical Reviews, 109, 1346-1370 (2009).

DOI: $\underline{10.1021 / \mathrm{cr} 8003828}$

[24] Lozinsky V. I., Domotenko L. V., Zubov A. L., Simenel I. A.: Study of cryostructuration of polymer systems. XII. Poly(vinyl alcohol) cryogels: Influence of low-molecular electrolytes. Journal of Applied Polymer Science, 61, 1991-1998 (1996).

DOI: 10.1002/(SICI) 1097-4628(19960912)61:11 $\leq 1991::$ AID-APP13>3.0.CO;2-2 
[25] Fortini M., Berti D., Baglioni P., Ninham B. W.: Specific anion effects on the aggregation properties of anionic nucleolipids. Current Opinion in Colloid and Interface Science, 9, 168-172 (2004).

DOI: $10.1016 /$ j.cocis.2004.05.025

[26] Papachia S.: Blends based on poly(vinyl alcohol) and the products based on this polymer. in 'Handbook of polymer blends and composites' (eds.: Vasile C., Kulshreshtha A. K.) Rapra, Shawbury, 288-365 (2003).

[27] Le Ny A-L. M., Lee C. T.: Photoreversible DNA condensation using light-responsive surfactants. Journal of the American Chemical Society, 128, 6400-6408 (2006).

DOI: $10.1021 / \mathrm{ja} 0576738$

[28] Baker J. P., Stephens D. R., Blanch H. W., Prausnitz J. M.: Swelling equilibria for acrylamide-based polyampholyte hydrogels. Macromolecules, 25, 1955-1958 (1992). DOI: $10.1021 / \mathrm{ma} 00033 \mathrm{a} 019$

[29] Piai J. E., de Moura M. R., Rubira A. F., Muniz E. C.: Kinetic study of bovine serum albumin (BSA) released from alginate- $\mathrm{Ca}^{2+} /$ PNIPAAm hydrogels. Macromolecular Symposia, 266, 108-113 (2008). DOI: $\underline{10.1002 / \text { masy. } 200850620}$

[30] Valente A. J. M., Polishchuk A. Y., Burrows H. D., Miguel M. G., Lobo V. M. M.: Sorption/diffusion behaviour of anionic surfactants in polyacrylamide hydrogels: From experiment to modelling. European Polymer Journal, 39, 1855-1865 (2003). DOI: $\underline{10.1016 / \mathrm{S} 0014-3057(03) 00108-3}$
[31] Djouadi Z., Bottani S., Duval M-A., Siebert R., Tricoire H., Valentin L.: Mobility and activation energy of single-stranded DNA in denaturing cross-linked polyacrylamide slab gels. Journal of Chromatography A, 894, 231-239 (2000).

DOI: $10.1016 / \mathrm{S} 0021-9673(00) 00700-7$

[32] Dias R. S., Lindman B., Miguel M. G.: Compaction and decompaction of DNA in the presence of catanionic amphiphile mixtures. The Journal of Physical Chemistry B, 106, 12608-12612 (2002).

DOI: $10.1021 / \mathrm{jp} 020392 \mathrm{r}$

[33] Dias R. S., Magno L. M., Valente A. J. M., Das D., Das P. K., Maiti S., Miguel M. G., Lindman B.: Interaction between DNA and cationic surfactants: Effect of DNA conformation and surfactant headgroup. The Journal of Physical Chemistry B, 112, 14446-14452 (2008). DOI: $\underline{10.1021 / j p 8027935}$

[34] Morán M. C., Miguel M. G., Lindman B.: SurfactantDNA gel particles: Formation and release characteristics. Biomacromolecules, 8, 3886-3892 (2007). DOI: $10.1021 / \mathrm{bm} 700850 \mathrm{z}$

[35] Morán M. C., Miguel M. G., Lindman B.: DNA gel particles: Particle preparation and release characteristics. Langmuir, 23, 6478-6481 (2007). DOI: $\underline{10.1021 / 1 a 700672 \mathrm{e}}$ 